\title{
Does the Payment Method Affect Patient Satisfaction? An Analytical Study in 10 Hospitals in Central Sulawesi
}

\author{
Indah Puspasari Kiay Demak ${ }^{1,2}$, Diah Mutiarasari ${ }^{1,2}$ \& Elli Yane Bangkele ${ }^{1,2}$ \\ ${ }^{1}$ Department of Public Health-Community Medicine, Medical School, Tadulako University, Palu, Indonesia \\ ${ }^{2}$ Tadulako University Hospital, Palu, Indonesia \\ Correspondence: Indah Puspasari Kiay Demak, Department of Public Health-Community Medicine, Medical \\ School, Tadulako University, Palu, Central Sulawesi, 94118, Indonesia. Tel: 62-451-422-611; Fax: \\ 62-451-422-844. E-mail: sashkata@yahoo.com
}

Received: March 11, 2019 Accepted: April 3, 2019 Online Published: April 15, 2019

doi:10.5539/gjhs.v11n5p123

URL: https://doi.org/10.5539/gjhs.v11n5p123

\begin{abstract}
Indonesia has started reforms in the health system over the past five years, aiming to increase access of all people to health services. At present, there is public concern about quality health services, where the success of hospitals in meeting patient expectations is a major determinant in increasing patient satisfaction and trust. Patient satisfaction is an important measure for the process of evaluating the quality of services to patients in hospitals. However, the evaluation of patient satisfaction based on their payment methods is still very limited. The purpose of this study was to measure differences in hospital service satisfaction based on payment methods in Central Sulawesi.

This an analytical observational study with a cross-sectional approach. Samples were taken using purposive sampling technique from 10 hospitals in Center Sulawesi. The samples were 107 respondents for each hospital or 1,070 respondents overall.

The highest overall level of patient satisfaction on all elements was experienced by respondents who paid using NHIS (77.50\%) while the lowest was felt by respondents who paid with KIS (70.74\%). The Kruskal Wallis test results for all elements indicated that there were significant differences in satisfaction levels based on the payment methods in all elements with $\mathrm{p}$-value $=0.000$, ( $\mathrm{p}$-value $<0.05$ ). The results of this study indicated that there were significant differences in satisfaction levels based on the payment methods in all elements of service.
\end{abstract}

Keywords: patient satisfaction, payment methods, hospital

\section{Introduction}

The World Health Organization (WHO) framework has recommended that, in the health sector, all member countries of the United Nations around the world have to organize the Universal Health Coverage (UHC). The UHC achievement target is valid until 2030 as part of sustainable health development goals. This framework has three main dimensions: coverage of the health care system, financial risk protection, and population. The health services department aims to monitor the progress of services such as promotive, preventive, curative, rehabilitative, and palliative health services (Chan, 2014; WHO, 2017). All of these are dynamic, synergies, and continuous processes in the midst of the enormous changes taking place in the health system today.

Health services must be provided with the best quality and the most economical price possible. Each country faces challenges in controlling the cost of health services and each country have its own policies in applying health insurance methods (Ellis et al., 2014). In some countries, the national health insurance scheme plays an important role in achieving UHC despite many challenges and problems that arise in its application. The success in dealing with these challenges depends on the efforts of key stakeholders, service providers, insurance members, and health policy makers (Alhassan et al., 2016).

The implementation of UHC in Indonesia has been carried out since January 1, 2019, with the concept similar to that in other countries, namely that the state guarantees that all Indonesian citizens have access to the health care system needed with effective and affordable service quality. The Indonesian government hopes they can improve access for the poor and disadvantaged, in accordance with the mandate of the 1945 Constitution and Law Number 40 of 2004 concerning the National Social Security System (NSSS). 
In the NSSS, a public legal entity to implement a social security program called the National Health Insurance Scheme (NHIS) was formed and officially operated on January 1, 2014. Since the implementation of NHIS, there have been many complaints from all health stakeholders and the community as users, including doctors as one of the professional caregivers. Poor socialization to the public regarding the system of using NHIS affects the service process, service quality, and patient satisfaction.

Patient satisfaction is a very important component for service in the hospital and is one of the main indicators that can bring an impact on the health service process given to patients, where, in the NSSS era, the method of service delivery is called "patient center care". The higher level of patient satisfaction will increase the number of patients who are loyal to the hospital so that it indirectly increases the operating income of the hospital. Patient satisfaction is also influenced by the payment method. Patients think that there are still differences in services obtained through personal funds, NHIS, and other commercial insurances. Based on this background, the researchers believe that it is very necessary to evaluate services in hospitals so that they can find out the level of satisfaction of patients based on their payment methods.

\section{Research Methods}

\subsection{Population and Sampling}

The study was conducted in 8 public hospitals (Anutapura Public Hospital, Undata Regional Public Hospital, Wirabuana Hospital, Kabelota Regional Public Hospital, Anuntaloko Regional Public Hospital, Bungku Regional Public Hospital, Mokopido Regional Public Hospital, and Luwuk Regional Public Hospital and 2 private hospitals (Budi Agung Hospital and The Salvation Army's Woodward Hospital) in Central Sulawesi Indonesia.

The subjects in this study were both outpatients and inpatients in 2016. The samples were selected using a purposive sampling technique. The minimum number of samples is calculated based on two proportion sample size formula with $95 \% \mathrm{CI}$ and $10 \%$ precision. By calculating the $10 \%$ drop out, the number of samples is 107 respondents for each hospital, so that the minimum number of samples for the 10 hospitals studied is 1070 people.

\subsection{Data Collection}

The data was collected using the Community Satisfaction Indexes (CSI) Questionnaire to measure the level of patient satisfaction. There were 38 closed questions that were arranged in accordance with the nine elements of the community satisfaction survey based on Ministry of Administrative and Bureaucratic Reform, namely (1) Element A: Requirements, which includes everything that must be met in the management of services, both in the form of technical and administrative requirements; (2) Element B: Procedure, which is a standardized service measure for providers and recipients of services, including complaints; (3) Element C: Service time, which is the period of time needed to complete the entire service process of each type of service; (4) Element D: Fees/rates, which includes fees charged to recipients of services to administer and/or obtain services from the service providers, the amount of which is determined by agreement between the service providers and the community; (5) Element E: Product specifications of the type of service, which includes the results of services provided and received in accordance with predetermined provisions and the results of each type of service specification; (6) Element F: Implementing competency, which is an ability that includes knowledge, expertise, skills, and experience that must be possessed by service providers; (7) Element G: Implementing attitudes, which includes the attitude of officers in providing services; (8) Element H: Notice of service, which is in the form of a statement on the ability and obligation of service providers in carrying out services in accordance with the service standards; and (9) Element I: Handling complaints, suggestions, and input, which is the procedure for implementing complaints handling and follow-up. ${ }^{5}$ The questionnaire used a Likert scale score 1 to 4 with the following descriptions: value 4 for "very satisfied" answers, value 3 for "satisfied" answers, value 2 for "dissatisfied" answers, and value 1 for "very dissatisfied" answers.

The questionnaire was completed by outpatients while waiting for drugs purchased in the pharmacist. On the other hand, it was fill in by inpatients who were taken care in the hospital for 3 days or more and those who have recovered and will go home while waiting for the hospital's administration.

\subsection{Data Analysis}

The level of patients' satisfaction was converse into a scale of 100 and categorized as follows: 
Table 1 . Service quality category

\begin{tabular}{llll}
\hline No & Service quality & Scale & \\
& & Scale of 100 & Scale of 1-4 \\
\hline 1. & A (Very good) & $81.26-100.00$ & $3.26-4.00$ \\
2. & B (Good) & $62.51-81.25$ & $2.51-3.25$ \\
3. & C (Average) & $43.76-62.50$ & $1.76-2.50$ \\
4. & D (Bad) & $25.00-43.75$ & $1.00-1.75$ \\
\hline
\end{tabular}

Furthermore, the data were analyzed by Kruskal Wallis test to compare the differences in patients' satisfaction based on payment methods.

\section{Results}

\subsection{Characteristics of the Respondents}

Out of 1070 respondents, a total of $711(66.5 \%)$ were outpatients and 359 (33.5\%) were inpatients. The number of female respondents (654 people) was higher than male respondents (415 people). The highest age range of respondents was $26-35$ years old $(25.9 \%)$ and the least was at age $>65$ years $(6.8 \%)$. Occupations of respondents varied, most of which were other occupations $(56.2 \%)$, which included housewives, students, farmers, or even unemployed people. Meanwhile, jobs as private employees had the least percentage (8.0\%). Most respondents had the latest education equivalent to high school, which was as many as 403 people $(37.3 \%)$, while the respondents who had attended post-graduate programs had the least number of only 13 people (1.2\%). More than half of the sample made payments using BPJS/NHIS, as many as 643 people $(60.09 \%)$, while those using other insurance payments (private insurance) were at least 31 people $(2.89 \%)$.

Table 2. Characteristics of the respondents

\begin{tabular}{|c|c|}
\hline Characteristics & Total $(n=1070)$ \\
\hline \multicolumn{2}{|l|}{ Gender } \\
\hline Male & $416(38.9 \%)$ \\
\hline Female & $654(61.1 \%)$ \\
\hline \multicolumn{2}{|l|}{ Age } \\
\hline$<17$ years old & $95(8.9 \%)$ \\
\hline $17-25$ years old & $164(15.3 \%)$ \\
\hline $26-35$ years old & $278(25.9 \%)$ \\
\hline $36-45$ years old & $212(19.8 \%)$ \\
\hline $46-55$ years old & $145(13.5 \%)$ \\
\hline $56-65$ years old & $103(9.6 \%)$ \\
\hline$>65$ years old & $73(6.8 \%)$ \\
\hline \multicolumn{2}{|l|}{ Occupation } \\
\hline Civil servant & $180(16.8 \%)$ \\
\hline Private employees & $85(7.9 \%)$ \\
\hline Entrepreneur & $204(19.1 \%)$ \\
\hline Others & $601(56.2 \%)$ \\
\hline \multicolumn{2}{|l|}{ Education } \\
\hline Elementary school & $149(13.9 \%)$ \\
\hline Junior high school & $238(22.2 \%)$ \\
\hline Senior high school & $403(37.3 \%)$ \\
\hline Undergraduate/Diploma & $267(24.9 \$ \%)$ \\
\hline Master's/Doctorate & $13(1.2 \%)$ \\
\hline
\end{tabular}




\section{Payment Method}

Self-funded

$179(16.73 \%)$

NHIS (National Health Insurance Scheme)

$643(60.09 \%)$

KIS (Healthy Indonesian Card)

$118(11.03 \%)$

JAMKESDA(Local Health Security)

$99(9.25 \%)$

Other insurance

$31(2.89 \%)$

\section{Types of Healthcare}

Outpatient care

\subsection{Patients'Satisfaction}

The means of overall satisfaction level was 75.99 ( \pm 11.28$)$, which fell into category B for service quality and "Good" for service performance ${ }^{5}$. The highest level of satisfaction was in element $\mathrm{F}$ of Implementing Competencies, reaching 78.25 ( \pm 13.48) and the lowest was in the element I Handling Complaints, Suggestions service quality and "Good" for service performance.

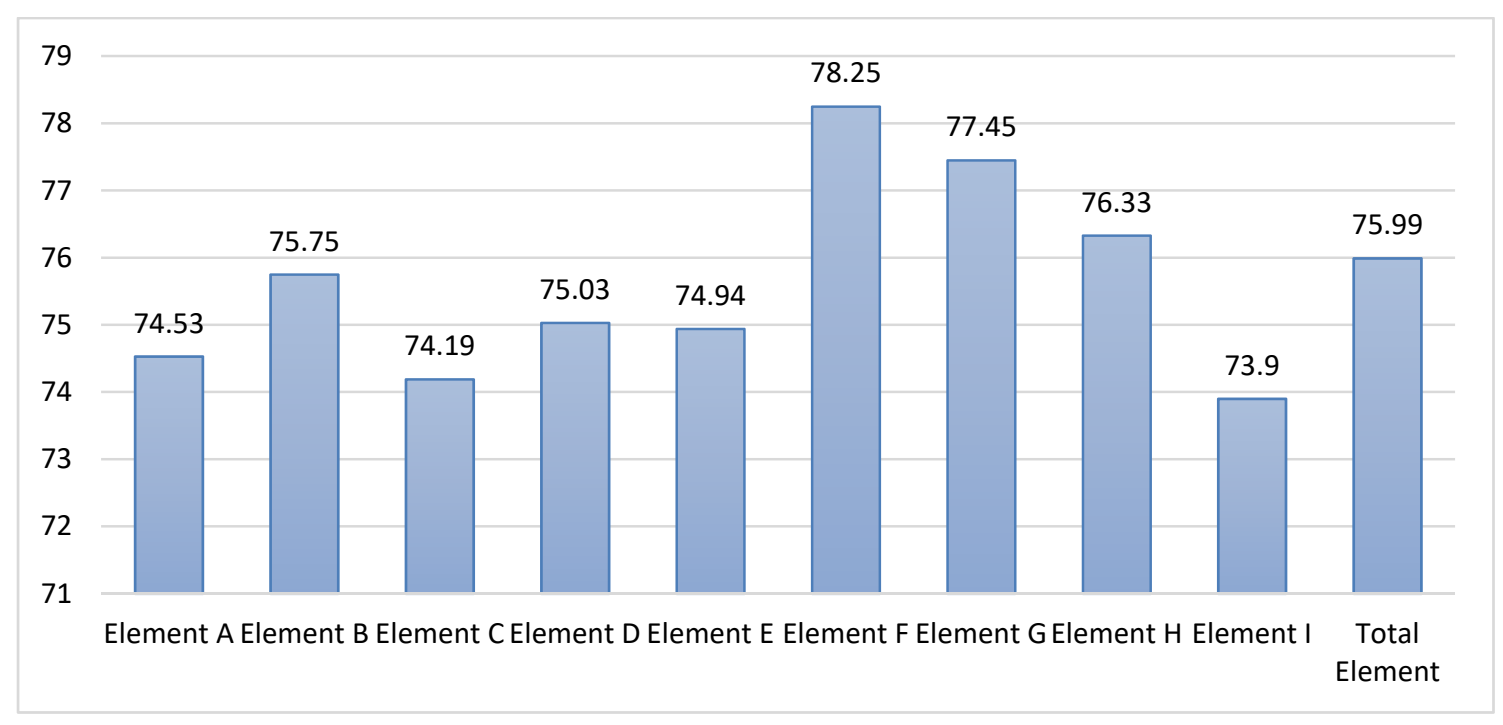

Figure 1. The overall satisfaction level

Moreover, patients' who paid using NHIS had the highest satisfaction, while those who used KIS had the least on all element. Except for element $C$ Service Time, those who were self-funded had the highest satisfaction, on the other hand, patients with other insurances had the lowest score. 


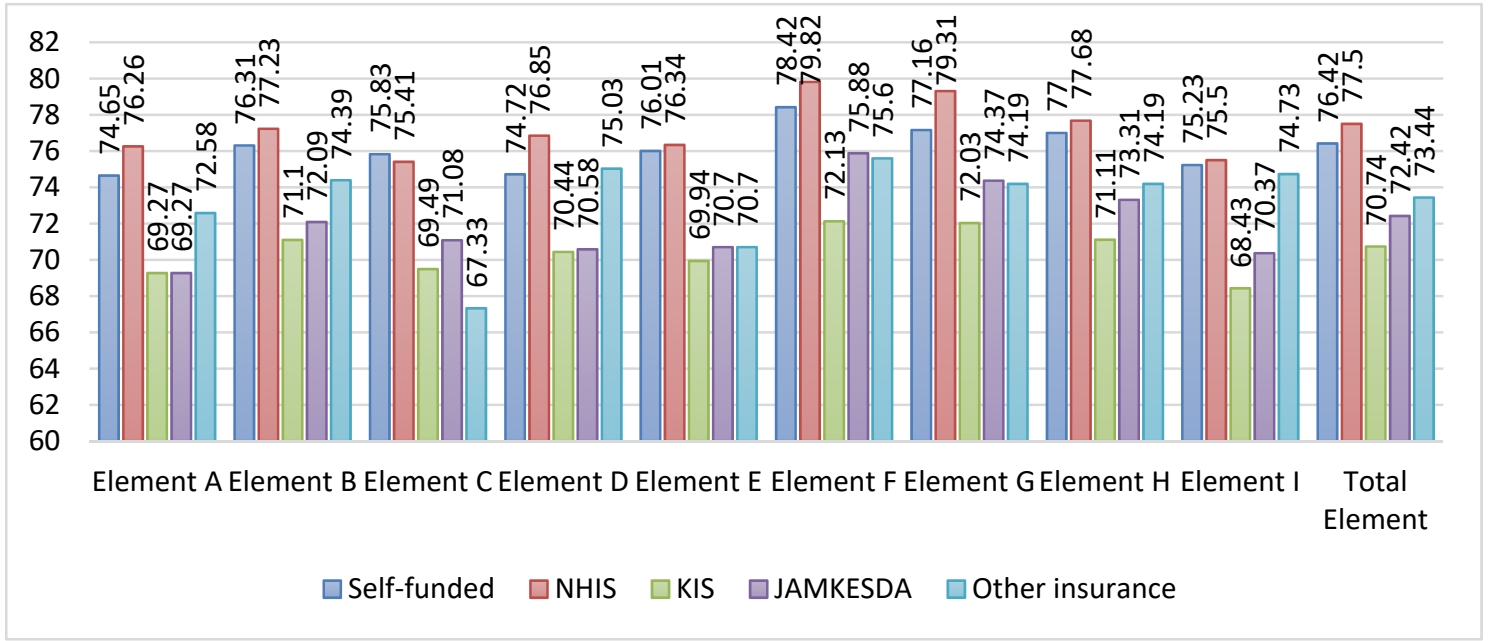

Figure 2. The level of satisfaction based on the payment methods

\subsection{Statistical Analysis}

The statistical analysis of Kruskal Wallis result showed that the p-value for all elements was below 0.05 , which means that there were differences between patients' satisfaction and payment methods in hospitals at Center Sulawesi. Besides, NHIS had the highest mean rank for all element, except for the element C Service Time and I Handling Complaints. On the other hand, KIS had the lowest mean rank for all element, except for the element C Service Time.

Table 3. The statistical analysis (Kruskal Wallis Test)

\begin{tabular}{lllllllllll}
\hline Element & A & B & C & D & E & F & G & H & I & Total \\
\hline Mean Ranks & & & & & & & & & & \\
Self-funded (N= 179) & 530.31 & 535.42 & 560.65 & 531.50 & 558.68 & 523.73 & 506.49 & 538.50 & 563.09 & 531.91 \\
NHIS (N=643) & 565.13 & 560.37 & 553.61 & 564.86 & 560.51 & 561.97 & 569.00 & 557.50 & 551.73 & 566.75 \\
KIS (N=118) & 447.28 & 430.69 & 458.59 & 457.32 & 440.18 & 423.84 & 424.55 & 439.41 & 439.16 & 422.65 \\
JAMKESDA (N=99) & 468.48 & 500.67 & 498.51 & 468.31 & 469.57 & 533.75 & 513.51 & 511.94 & 482.99 & 489.22 \\
Other insurance (N=31) & 500.65 & 530.27 & 425.45 & 461.76 & 456.26 & 485.08 & 500.74 & 502.79 & 573.89 & 485.32 \\
\hline P value (CI 95\%) & 0.000 & 0.000 & 0.001 & 0.000 & 0.000 & 0.000 & 0.000 & 0.000 & 0.000 & 0.000 \\
\hline
\end{tabular}

\section{Discussion of Results}

This study was conducted to compare patient satisfaction levels based on their payment methods in 10 hospitals in Central Sulawesi Province. CSI (Community Satisfaction Index) research results on service quality showed that all elements of service, which were based on indicators described in the Decree of the Minister of Administrative and Bureaucratic Reform No. 25/M.PAN/2/2004 concerning General Guidelines for the Creation of the Community Satisfaction Index (CSI), fell into category B for service quality and "Good" for service performance, with the total satisfaction of 75.99 (11.28) in all elements. Increasing elements of service speed, service certainty, and service costs were very priority to support the National Health Insurance program with quality control and cost control (Astiena et al., 2014). The results of a study in Bangladesh found that the overall level of satisfaction with health services by means of an insurance scheme payment was satisfactory with an average satisfaction score of $4.17 \pm$ 0.04 (95\% CI: 4.08-4.26) of 5.00, but this satisfaction rate could still be improved. The most satisfying components were regarding diagnostic services, prescribed drugs explanation, environments around health facilities, and behavior of health workers towards patients. Studies related to patient satisfaction can contribute to the design of the health system with an insurance scheme accompanied by a public health financing strategy to develop health insurance as part of achieving UHC (Sarker et al., 2018). 
The results of this study indicated that the highest level of patient satisfaction in all elements was from the respondents who paid using NHIS and the lowest was from the respondents who paid with KIS, except for element C Service Time, in which the highest level of satisfaction was from the respondents with his own funding and the smallest was from the respondents with other insurance payments. In addition, the Kruskal Wallis test for all elements showed that there were significant differences in satisfaction levels based on the payment methods for all elements (p-value $<0.05$ ). Similarly, the results of Fenny et al., (2014) study indicated that a higher proportion of patients expressed satisfaction was from those who used insurance as the payment method. Patients were satisfied with the waiting time, the staff friendliness, and the consultation process. The results of this study indicated that prioritizing quality in treating a patient in health facilities was important. In contrast, Tangcharoensathien et al., (1999) research suggested that self-pay patients who paid normal rates were more satisfied than those who paid using social security. Patients who used social security in Thai hospitals did not get enough attention when consulting with a doctor.

The results of the study on the element of requirements and service procedure showed that patients with NHIS payment method were more satisfied with the conditions that must be met for managing services, both technical, administrative requirements and service procedures in the hospitals, compared to patients with non- NHIS payment methods. It was supported by the opinion of the respondents (patients) that most of them were satisfied with the service at the Central Sulawesi Provincial Hospitals in Indonesia, where the hospitals already had an information system regarding the registration administrative requirements for its patients and clear service flow. Additionally, the hospital also facilitated the service procedures and complaints, and the medical personnel provided an informed consent form to a patient for every medical treatment that would be taken. In Indonesia, NHIS routinely held socialization to the community since it had been implemented five years ago. It was socialized to the government and the private institutions at the provincial, district and sub-district levels through printed and electronic media, face-to-face interaction and presentations in each seminar. Those socialization techniques were done to make people understand the terms and procedures of hospital services in Indonesia. Ariningtyas (2017) research found similar results, stating that patients with the NHIS payment method were more satisfied with the ease of requirements with a mean of 4.0 (satisfactory). The ease of administration procedure was very important because patients who had been allowed to go home wanted to return home immediately to get a comfortable environment and ease of administration, including the manifestation of one of the effective efforts to improve patient satisfaction. In contrast, research carried out by Quynh \& Dhar (2014) showed that patients who paid using insurance were completely dissatisfied with health care procedures, especially during registration and consultation.

The results of the research on the element of service time showed that self-pay patients were more satisfied than patients with health insurance. It shows that the majority of patients who paid by themselves got a very well served, especially in the emergency department (ED). The response time to emergency patients was handled for a maximum of 5 minutes from their arrival time at the emergency room and the doctor gave sufficient time to the patient. Moreover, the waiting time in hospital pharmacy was less than 60 minutes for compounding medicine and less than 30 minutes for patent medicine. It is in accordance with the minimum service standards issued by the Indonesian Ministry of Health. In line with Tangcharoensathien et al., (1999) study which showed that self-pay patients received more service time from the doctor, including having complete medical history data. In contrast, Garba et al., (2018) research found that patients with more insurance at Aminu Kano Education Hospital were satisfied at the time of consultation with the doctor (88.7\%), compared to non-insurance patients. Chairunnisa \& Puspita (2017) research revealed that the majority of NHIS patients were satisfied with the attributes of service time at Jakarta Islamic Hospital in Indonesia, which reached 56.4\%.

The results of the research on the cost element indicated that NHIS patients were more satisfied than self-pay patients or those who paid using other health insurance. This is in line with one of NSSS principles in Indonesia called mutual cooperation that the NHIS collects contributions paid by the community and they are used for financing the operational costs of its members who are sick. This principle is applied because there are still many underprivileged Indonesians who need treatment in health facilities. The Indonesian government regained the community culture and character of mutual cooperation in its health system. The Data from NHIS states that 1 patient diagnosed with dengue hemorrhagic fever was financed by 80 healthy participants, 1 patient with caesarian section was funded by 135 healthy participants, and 1 patient diagnosed with cancer was paid by 1,253 healthy participants. The concept of mutual cooperation not only belongs to NHIS but also belongs to Indonesians. By applying this principle, most people/patients are very satisfied to the insurance payments strategy. In addition, the cost paid by patients is relevant with the costs set by each hospital and the cost is relatively affordable by Indonesians in all levels of society. This finding was supported by the Garba et al., (2018) study, showing that 
patients with an insurance payment method were more satisfied with the costs once the patient had finished the treatment $(90.0 \%)$ than non-insurance patients and the results of multivariable logistic regression of satisfaction with the payment of costs once the patient had finished the treatment (adjusted OR; 95\% CI: 0.40;0.21, 0.83) determined the satisfaction at the hospital. Increasing coverage of the NHIS can improve patient access to and satisfaction with health services in hospitals. In contrast, Rahmayanti \& Ariguntar (2017) found that most patients received health services by paying using their own money (77.9\%). This showed that the existence of the NHIS program had little effect on service rates because the NHIS administration process required a long time and a long process.

The results of the research on the product specifications of the type of service indicated that NHIS patients were more satisfied with the types of health services provided and received in accordance with applicable regulations in the hospital compared to non- NHIS patients. In addition, other supporting facilities such as buildings are clean and waiting rooms are quite comfortable. Each room in a hospital has complete and standardized equipment. It makes patients feel comfortable while getting their treatments. The NHIS involvement in maintaining the provision of quality services is strongly supported by the hospitals. It routinely monitors and evaluates the hospitals to ensure that NHIS participants in Indonesia have received appropriate services. This was supported by Sarker et al., (2018) research which mentioned the satisfaction with comprehensive services provided by health facilities from patients using the insurance scheme, with a mean of $4.09 \pm 0.85$ (95\% CI: 3.98-4.20) of 5.00.

The results of the study on the elements of implementing competency showed that NHIS patients were satisfied with the competencies of health workers which included knowledge, skills, expertise, and experience in each hospital. In this case, doctors in Indonesia have sufficient knowledge and skills in providing appropriate, fast and accurate services to patients. The patients in this study were satisfied because each question during the consultation was able to be well and clearly answered by the doctors. As a result, they felt comfortable, safe and confident about the treatment they would receive. This was supported by Hidayah (2015) research which found that NHIS patients stated that one of the attributes that were very important and very satisfying and that could influence patient satisfaction was the ability of the doctor. In growing and applying medical ethics, especially when forming good relations between doctors and patients, communication skills are very necessary. Improving the effective communication skills of hospital officials is a major concern of hospital management because good communication can be the most effective way to improve patient satisfaction with services.

The results of the study on the elements of implementing behavior showed that NHIS patients were more satisfied with the behavior of health workers. In general, most of the hospitals' health workers treat all patients in the same manner. Doctors, nurses, and other officers are appropriately dressed, polite and friendly. They respect all patients. Moreover, NHIS applied a prior health care system with the concept of Patient-Centered Care (PCC) with integrated patient care. Each hospital employee's treatment in providing patient services is based on patients' needs prioritizing service quality and safety, and evidence based medicine. Indonesians are satisfied with the changes in officer behavior and consistency in providing care to the patients. This was supported by Fenny et al., (2014) research which found that patients with insurance payments were very satisfied (32.8\%) and satisfied (57.5\%) with the hospitality of hospital medical staff compared to patients with the non-insurance payment method. Following the Donabedian process-structure model, the results showed a significant difference between groups of patients with insurance and non-insurance methods related to perceptions of hospitality of the medical staff. Logistic regression test results of patient satisfaction with friendliness showed p-value $=0.000$ and OR; $95 \%$ CI: 3.02; 2.19 , 3.85. The results of this test showed that the hospitality of the medical staff was one of the predictors of overall patient satisfaction with service quality. In addition, interpersonal relationships held the key to success in increasing patient satisfaction. In another study, Garba et al., (2018) showed that patients with insurance payments were more satisfied with the behavior of doctors who would listen attentively, spend enough time with patients, explain what patients need to know about the course of their illness, and provide advice and input during patient treatment well compared to non-insurance patients. According to patients with insurance, overall they were satisfied with all services received from doctors, with $\mathrm{P}$ value $=0.004$.

The results of the study on the elements of the notice of service, patients were more satisfied with the payment method using NHIS compared to other payment methods. This is in accordance with the mandate of the Republic of Indonesia Law Number 4 of 2018 concerning hospital obligations and patient obligations, that the hospitals to provide safe, quality, anti-discriminatory, and effective health services for patients according to hospital service standards

The results of the study on the elements of handling complaint, suggestions, and feedback indicated that patients who paid with NHIS were more satisfied than non- NHIS patients. It is because any hospital that intends to 
collaborate with NHIS must fulfill one of the hospital credential requirements. The hospital must have a special room to receive complaints, suggestions, and feedbacks from NHIS patients. Their satisfaction in getting hospital services has always been a priority for NHIS. In addition, special staff is appointed to manage any patient's complaint at the hospital. It is to facilitate good coordination between the three parties (NHIS, hospital, and patients). This was supported by Chairunnisa \& Puspita (2017) research which found that, based on their payment status, most patients used NHIS (70.9\%). In this study, health workers, especially doctors and nurses, were quick to respond to patient complaints and suggestion boxes were available in hospitals. The attitude of hospital staff played an important role in providing health services to patients and could affect and even reduce the patient satisfaction rate (Fenny et al., 2014).

The hope of the Indonesian Government in the world of health is that there is no difference in the provision of good health services for NHIS and non- NHIS patients. Whatever form of insurance the Indonesian people use, they will all get the same treatment for services, namely getting the same fast and appropriate service, getting the same facilities and infrastructure in accordance with the treatment class, obtaining drugs according to disease diagnosis, and giving the same friendly service to all patients, so they can support the NSSS in achieving the UHC target, where all Indonesians have health insurance to obtain the benefits of maintenance and protection in meeting basic health needs. Thus, there is no difference in patient satisfaction in receiving quality services in accordance with health service standards and accreditation service standards (Ariningtyas, 2017; Hidayah, 2015).

The hospital as one of the health facilities is expected to be able to provide effective and efficient services. The problem that is often faced in general by hospitals is that it has not been able to provide services that are in accordance with the service standards and the established legislation. Thus, it affects the level of patient satisfaction when patients do not get services according to their expectations. Various efforts can be made to increase patient satisfaction with hospital services, namely (1) at the individual level, each professional caregiver improves professional proficiency, communication and empathy skills to patients and applies medical standards and medical professional ethics in daily practice, (2) at the institutional level, the hospital prioritizes patients' safety and security, supports resources in hospital operations, gives manageable workload to employees, provides remuneration based on skills and accountability, and improves the hospital administration system with innovative approaches, (3) at the national level, improvement is needed in health system policies both in terms of benefits and equality in obtaining health services for people registered as users of social security (Woldeyohane et al., 2015; Shan et al., 2016; Salesman et al., 2018; Nkwinda et al., 2019). In addition, the government must also ensure that all health facilities, especially hospitals, have complied legislation and guidelines for national health insurance through monitoring, evaluating, and maintaining the quality of service on a regular basis (Daramola et al., 2018). The Indonesian government also stipulates that each hospital must be accredited by the hospital accreditation committee, so it is hoped that if the hospital is standardized, the quality of service and patient safety can be sustainable.

\section{Conclusion}

There were significant differences in satisfaction levels based on the method of payments. The level of satisfaction of patient with NHIS was higher than those with other insurance or without insurance. This is because access to health services for poor people is easier, services are the same as non-insurance, and low fees. The condition indicates that there is an increased awareness of the importance of health so that the target of achieving UHC in the NSSS in Indonesia can be considered successful.

\subsection{Ethical Considerations}

Ethical issues (Including plagiarism, informed consent, misconduct, data fabrication and/or falsification, double publication and/or submission, redundancy, etc.) have been completely observed by the authors.

\subsection{Limitation}

Some limitation of this study is the number of subjects that are not evenly distributed according to the method of payment. Subjects with the NHIS are far more than other payment methods. In addition, there are too many questions that making the subject get bored quickly. So that it can affect the validity of answers from the subject.

\subsection{Recommendations}

1. Carry out "service excellent" training in hospitals, so that there are no differences in the types and quality of services provided to patients, except based on treatment classes.

2. Monitor and evaluate at the level of patient satisfaction at the hospital continuously and periodically. 


\section{Acknowledgments}

The research was supported by the Central Sulawesi Health Office.

\section{Competing Interests Statement}

The authors declare that there are no competing or potential conflicts of interest.

\section{References}

Alhassan, R. K., Amponsah, E. N., \& Arhinful, D. K. (2016). A review of the national health insurance scheme in Ghana: what are the sustainability threats and Prospects? PLoS ONE, 11(11), e0165151. https://doi:10.1371/journal. pone.0165151

Ariningtyas, Y. A. (2017). Perbandingan kepuasan pasien terhadap pelayanan kebidanan pada peserta BPJS dan Non BPJS. Program Studi Magister Kebidanan, Fakultas Ilmu Kesehatan Universitas Aisyiyah. Tesis. Yogyakarta. Retrieved from http://digilib.unisayogya.ac.id/2457/1/Publikasi\%20FULL.pdf

Astiena, A. K., Liputo, N. I., Evianti, S., \& Sulistyawati, D. (2014). Pengukuran kepuasan pasien berbasis metode KEPMENPAN nomor 25 Tahun 2004. Majalah Kedokteran Andalas, 37(30). https://doi.org/10.22338/mka.v37.i3.p167-173.2014

Badan Penyelenggara Jaminan Sosial (BPJS). Kesehatan. Retrieved from https://bpjs-kesehatan.go.id

Badan Penyelenggara Jaminan Sosial (BPJS). Kesehatan. (2017, November 1). Dukung keberlangsungan JKN-KIS Mendaftarlah selagi sehat. Majalah Info BPJS Kesehatan, 6-9. Retrieved from https://bpjs-kesehatan.go.id/bpjs/dmdocuments/5763165a1542a628e8517b4cc05aacb8.pdf

Chairunnisa, \& Puspita, M. (2017). Gambaran kepuasan pasien rawat jalan terhadap pelayanan di Rumah Sakit Islam Jakarta Sukapura Tahun 2015. Jurnal Kedokteran dan Kesehatan, 13(1), 9-27. https://doi.org/10.24853/jkk.13.1.9-27

Chan, M. (2014). WHO Director-General addresses the economic dimensions of universal health coverage. Retrieved January 4, 2019, from https://www.who.int/dg/speeches/2014/uhc/en/

Daramola, O. E., Adeniran, A., \& Akande, T. M. (2018). Patients satisfaction with the quality of services accessed under the National Health Insurance Scheme at a Tertiary Health Facility in FCT Abuja, Nigeria. Journal of Community Medicine and Primary Health Care, 30(2), 90-97. Retrieved January 8, 2019, from https://www.researchgate.net/publication/331895279

Ellis, R. P., Chen, T., \& Luscombe, C. E. (2014). Comparisons of health insurance systems in developed countries. Encyclopedia of health economics, (Vol. 1, pp. 396-406). San Diego: Elsevier Press., Inc. Retrieved January 8, 2019, from https://tianxuchen.weebly.com/uploads/2/2/8/1/22817854/2014_ellischenluscombe_ healthinsurancesystems_encyclopediaofhealtheconomics.pdf

Fenny, A. P., Enemark, U., Asante, F. A., \& Hansen, K. S. (2014). Patient satisfaction with primary health care - a comparison between the insured and non-insured under the National Health Insurance Policy in Ghana. Global Journal of Health Science, 6(4), 9-21. https://doi.org/10.5539/gjhs.v6n4p9

Garba, M. R., Gadanya, A. M., Lliyasu, Z., \& Gajida, A. U. (2018). Comparative study of patients' satisfaction between national health insurance scheme-insured and un-insured patients attending a northern nigerian tertiary hospital. Niger J Basic Clin Sci, 15, 118-26. https://doi.org/10.4103/njbcs.njbcs_48_16

Hidayah, T. N. (2015). Kepuasaan pasien BPJS non PBI terhadap kualitas pelayanan provider tingkat pertama dokter keluarga di Kecamatan Laweyan Surakarta (Program Studi Magister Manajemen, Program Pascasarjana Universitas Muhammadiyah Surakarta. Tesis. Surakarta). Retrieved from http://eprints.ums.ac.id/38946/1/Halaman\%20Depan.pdf

Kementerian Pendayagunaan Aparatur Negara. Keputusan Menteri Pendayagunaan Aparatur Negara Nomor 25 Tahun 2004 Tentang Pedoman Umum Penyusunan Indeks Kepuasan Masyarakat Unit Pelayanan Instansi Pemerintah. Jakarta. Retrieved January 4, 2019, from http://fapet.ub.ac.id/wp-content/uploads/2013/03/Kep-Men-PAN-25-Th-2004-Ttg-Pedoman-Umum-Penyus unan-IKM.pdf

Nkwinda, B., Jacobs, W., \& Downing, C. (2019). Patient Satisfaction With Caring at a District Hospital in Malawi. Global Journal of Health Science, 11(1), 15-27. https://doi.org/10.5539/gihs.v11n1p15

Peraturan Menteri Kesehatan Republik Indonesia nomor 4 tahun 2018 tentang kewajiban rumah sakit dan kewajiban pasien. Jakarta. Retrieved January 4, 2019, from, 
https://www.persi.or.id/images/regulasi/permenkes/pmk42018.pdf

Quynh, N. T., \& Dhar, N. (2014). A study of satisfaction among poor patients holding health insurance card with health care services at two district public hospital in Vietnam. Health dan Population Perspectives and Issues, 37 (1 \& 2): 50-56. Retrieved January 8, 2019, from http://medind.nic.in/hab/t14/i1/habt14ilp50.pdf

Rahmayanti, S. N., \& Ariguntar, T. (2017). Karakteristik responden dalam penggunaan jaminan kesehatan pada era BPJS di puskesmas Cisoka Kabupaten Tangerang Januari-Agustus 2015. Jurnal Medicoeticolegal dan Manajemen Rumah Sakit, 6(1), 61-65. https://doi.org/10.18196/jmmr.6128

Salesman, F., Tualeka, A. R., \& Bolilera, M. D. (2018). The Controversy of Views About Health Service Quality Between Health Provider and Patients with BPJS Insurance: A Case Study in Mamami Hospital-Kupang. Global Journal of Health Science, 10(9): 18-24. https://doi.org/10.5539/gjhs.v10n9p18

Sarker, A., Sultana, M., Ahmed, S., Mahumud, R., Morton, A., \& Khan, J. (2018). Clients' Experience and Satisfaction of Utilizing Healthcare Services in a Community Based Health Insurance Program in Bangladesh. International journal of environmental research and public health, 15(8), 1637. https://doi.org/10.3390/ijerph15081637

Shan, L., Li, Y., Ding, D., Wu, Q., Liu, C., Jiao, M., ... \& Wang, L. (2016). Patient satisfaction with hospital inpatient care: effects of trust, medical insurance and perceived quality of care. PloS one, 11(10), e0164366. https://doi.org/10.1371/journal.pone.0164366

Tangcharoensathien, V., Bennett, S., Khongswatt, S., Supacutikul, A. N. U. W. A. T., \& Mills, A. (1999). Patient satisfaction in Bangkok: the impact of hospital ownership and patient payment status. International Journal for Quality in Health Care, 11(4), 309-317. https://doi.org/10.1093/intqhe/11.4.309

Undang - Undang Republik Indonesia Nomor 40 Tahun 2004 Tentang Sistem Jaminan Sosial Nasional. Jakarta.http://www.jkn.kemkes.go.id/attachment/unduhan/UU\%20No.\%2040\%20Tahun\%202004\%20tenta ng\%20SJSN.pdf (accessed on January 4, 2019).

WHO. (2017). Universal Health Coverage (UHC). In Fact Sheets. Retrieved January 4, 2019, from http://www.who.int/en/news-room/fact-sheets/detail/universal-health-coverage-(uhc)

Woldeyohanes, T. R., Woldehaimanot, T. E., Kerie, M. W., Mengistie, M. A., \& Yesuf, E. A. (2015). Perceived patient satisfaction with in-patient services at Jimma University Specialized Hospital, Southwest Ethiopia. BMC research notes, 8(1), 285. https://doi.org/10.1186/s13104-015-1179-8

\section{Copyrights}

Copyright for this article is retained by the author(s), with first publication rights granted to the journal.

This is an open-access article distributed under the terms and conditions of the Creative Commons Attribution license (http://creativecommons.org/licenses/by/4.0/). 